Sarah Sayce BSc PhD FRICS

is head of the School of

Surveying at Kingston

University, responsible for a

range of RICS-accredited

undergraduate and

postgraduate courses. Vice-

chairman of the Leisure

Property Forum, a new

multidisciplinary organisation

dedicated to promoting

knowledge and understanding

of the industry, Dr Sayce was

a specialist assessor for the

British government during its

recent assessment of surveying

education.

Judy Smith BSc MRICS PGDipProperty Investment is Senior Lecturer in the School of Surveying at

Kingston University where she specialises in Property

Investment. She is co-author,

with Timothy Eccles and

Sarah Sayce of Property and

Construction Economics.

Philip Walker

is Associate Director,

Valuations, Insignia Richard

Ellis, London

Keywords:

commercial leisure leases, rent

reviews, rental growth, yield

change, returns, leisure economic

trends, multiplex cinemas
Dr Sarah Sayce

Head of School,

School of Surveying,

Kingston University,

Knights Park,

Kingston upon Thames, Surrey,

$\mathrm{KT} 1$ 2QJ London, UK

Tel: +44 (o) 2085477070

Fax: +44 (o) 2085477087

E-mail: s.sayce@kingston.ac.uk

\section{From estimate to actuality: Is the new leisure dream being realised?}

\author{
Sarah Sayce, Judy Smith and Philip Walker \\ Received: 18th April, 2001
}

\begin{abstract}
This paper develops a theme introduced by Sayce ${ }^{1}$ which tracked the development of the so-called 'new-style' leisure leases that have emerged over recent years consequent to a rapid increase in the number of commercial leisure developments in the UK. Prior to the development of these parks, leisure property ownership had been characterised by fragmented ownership and a diversity of lease patterns. $^{2}$ The research identified that the new leisure leases had been moulded to meet investor requirements but that many had distinguishing, and to the tenant onerous, clauses, notably in respect of rent reviews.

Last year the effect of these new-style rent review clauses and their impact on long-term viability from both an investor and an operator standpoint was raised, but there was insufficient empirical evidence to draw any meaningful conclusions. In this paper the authors explore the issues that are being raised in relation to leisure rent reviews in the light of market conditions. They also analyse rental trend evidence in relation to relevant economic data to develop an understanding of performance in real terms. In both cases the analysis concentrates on multiplex cinemas, which, they argue, are illustrative of the challenges facing the profession in relation to the management of commercial leisure assets.

The implications of the findings relate to both the security of the income flow and the justification of current market yields. The paper argues that this brings into question the long-term validity of the current arrangements and presents an agenda of potential conflicts that are likely to arise over the ensuing period in relation to rent reviews. It concludes first that the issues arising in the cinema market are transferable across most leisure properties and other categories such as nursing homes, and secondly that the nature of the lease terms are not conducive to the development of good landlord and tenant relationships.
\end{abstract}

\section{INTRODUCTION}

In an earlier issue of the Journal of Leisure Property, Sayce ${ }^{3}$ considered some of the implications lying behind the rise of investment interest in commercial leisure properties. It was reported that the later years of the 1990s had witnessed a rapid increase in 


\section{'Institutional' lease forms}

\section{Growth in institutional ownership}

investor interest in leisure investments. This presented a striking contrast from the situation some decade previously, when no institutional interest in leisure was evident. ${ }^{4}$ The relatively fast change in attitudes among investors was associated with the changing type of supply and the growth of the leisure park concept. It was also associated with changing lease patterns.

The new leases, superficially at least, resembled the institutional lease' form that had become the norm for UK commercial properties during the period since the early 1970s. In the light of lessee-led moves away from standard institutional leases in other commercial property markets ${ }^{5}$ the new leisure leases were observed to have been an encouragement to the growth of institutional investment. This in turn had led to suggestions that the commercial leisure investment sector would follow a similar pattern to that experienced in respect of retail warehouses. ${ }^{6}$ In the case of retail warehouses, the growth in supply was accompanied by rapid rental growth, which led to very significant increases at first rent review, and this in turn helped to establish retail warehouses as a recognised and recognisable sub-sector of the retail investment market.

Throughout the 1990s there was an increasing supply of commercial leisure properties, ${ }^{7}$ to a point at which they formed a significant, if minor, part of the UK commercial property stock. ${ }^{8}$ The last years of the decade saw a simultaneous decline in yields. ${ }^{9}$ Much of the development has taken place in the form of leisure parks, located either out of town or on the edge of town, but towards the end of the decade and consequent to changes in development control guidance, ${ }^{10}$ development activity has been concentrated in town centres and often integrated with retail uses. ${ }^{11}$ It is estimated that some 100 leisure parks were developed over the decade. ${ }^{12}$

At the beginning of the decade leisure park ownerships were concentrated within the property company and leisure sector and there was too little of a transaction base to quote yields realistically. ${ }^{13}$ With the growth in institutional interest this has changed, and from yields in the mid-1990s in excess of 10 per cent ${ }^{14}$ by 1999 prime yields were estimated to be between $6-6.5$ per cent. ${ }^{15}$

Throughout, the emphasis has been on multi-tenanted schemes. These have typically been anchored on a multiplex cinema. ${ }^{16}$ More recent developments have been constructed in existing developed areas and integrated with retail schemes (for example, O2, Finchley Road, London) or have been developed as part of regeneration initiatives (for example, Valley Centertainment, Sheffield). In each case the multiplex has been an important element in creating the whole investment.

The previous paper by Sayce $^{17}$ analysed the type of leases that were prevalent in the commercial leisure market and compared these to the changing pattern of lease structures in the rest of the UK commercial property market. It was shown that whereas a fragmentation of lease patterns and a general shortening of lease 


\section{Lessor protection at review}

\section{Occupational need for flexibility}

Issues at rent review length were occurring generally in the commercial property markets, ${ }^{18}$ the same was not true for leisure leases. The research demonstrated that most of these were of at least 20-35 years in duration. Very few leases, if any, were for less than 20 years. An examination of the key features of the leases revealed the onerous nature of rent review clauses which operated at the higher end of the range of open market rental values, established by comparable lettings, or a built-in escalator, typically 3 per cent per annum compound.

The aim of such clauses was to ensure that investing owners were not dependent entirely on underlying rental growth to achieve an increase in income flow at review. This practice represented a significant departure from the previous convention of fixing rents in relation to profitability in the hands of the efficient operator. ${ }^{19-22}$

This change in lease practice appeared to present a paradox. The leisure industry is best known for being fast moving and reacting to fashion and trends among customer behaviour to such a point that it is argued that it is not reactive to customer desires, but is proactive in creating the demand. ${ }^{23}$ With reductions in the time available for leisure ${ }^{24}$ the emphasis shifts to the inventiveness of marketing organisations to develop formats that can be sold as 'quality experiences' - and not just activities. To counteract the stress associated with work and appeal to those who are time constrained but economically powerful, it is necessary to supply the so-called 'fourth level of service' to meet the changed nature of demand. ${ }^{25}$ For this level of service the quality of the overall 'experience' is vital.

Logically, premises requirements for leisure industry operators would be designed for flexibility and short-term commitment. Prior to the rise of institutional investment interest in commercial leisure, this need for flexibility and change had been satisfied mainly within owner-occupied portfolios. The position at the end of the 1990s was that the leisure property sector was beginning to be associated with tenure patterns that were among the most rigid within the property markets.

The conclusion reached previously was that the rigidity inherent in the new leisure leases was, partly at least, driven by property companies and developers in their quest to create institutionally acceptable vehicles. They were observed to have been successful in developing a leisure property product which had been 'packaged up' in ways that, for the first time, made it attractive to institutional investors. This, it was argued, raised a series of potential issues for investors as the schemes moved towards rent reviews.

This paper takes this work one step further by providing a more in-depth analysis of one element within the commercial leisure schemes to establish whether, to date, the movement by investors into the sector is producing the benefits expected. It highlights the issues that are beginning to face those charged with the management of the assets, in respect of both rent review 


\section{Relation to A1} alternate use

\section{A growing oversupply?}

\footnotetext{
Growth of the multiplex
}

negotiations and capital valuations. For the purposes of this paper the investigation has centred on multiplex cinemas, as these are the key feature in most leisure schemes.

\section{THE NEW LEISURE LEASES}

The previous findings, based on research conducted in 1999, indicated that not only were leases normally of 25 years in length, but that the rent review clauses provided for some form of landlord protection. Typically, for cinemas, these were found to take the form of a review to the higher of:

- open market rental value (OMRV) or

- the initial rent increased at 3 per cent per annum compound.

In other leisure leases there was provision for stepped increases or a fall-back provision to value for alternate use (typically A1) ${ }^{26}$ Very few leisure leases, other than restaurants and ten-pin bowling, had simple OMRV clauses. None had upward and downward provision. The nature of the rent reviews suggested a continuing lack of investor confidence in leisure at the time that the leases were executed. Landlords had needed some additional security to provide an incentive to invest.

The conclusion reached was that the development of leisure parks was founded on an assumption that the growth of leisure as an economic good would justify the establishment of a rigid longterm relationship between landlord and tenant. ${ }^{27}$ It questioned the validity of this assumption, and raised concerns at a theoretical level over whether the tenure patterns so created were sustainable over the length of the lease due to:

- a lack of mutuality in investor and operator objectives;

- an overdependence on a few covenanting tenants;

- the inflexible nature of both structures and leases compared to rapid developments in user requirements.

Over the last year, concerns have been expressed about the level of demand for some leisure uses and well-publicised corporate moves and takeovers have pointed to a possible oversupply within the cinema market. ${ }^{28,29}$ This paper investigates these concerns and seeks to provide a better understanding of the property valuation and management issues that result, in the light of the lease structures.

\section{A BACKGROUND TO THE MULTIPLEX CINEMA}

The first multiplex cinema constructed in the UK was The Point in Milton Keynes, which opened some 15 years ago. This was, by the standards of current specification, both small and simple, having only six screens. The development was timely and coincided with the year in which cinema attendance began to revive, after having declined over a 30-year period. 


\section{Changing specification of multiplexes}

\section{Technology changes}

\section{Queries over future growth}

The reasons for the renaissance of the cinema as a form of entertainment are outside the scope of this paper, although it has been argued that one of the prime reasons for its re-emergence lay in the nature of the property provision. ${ }^{30}$ Wider socio-economic trends have seen leisure become less internal to the home and more an expression of manipulated consumer products marketed to the predominantly affluent sectors of society. Consequent to these, there has been a shift in the type of leisure 'product' offered, with provision increasingly being targeted towards the more affluent members of society, as argued by, for example, Ravenscroft. ${ }^{31}$

Over the period since the opening of the first UK multiplex cinemas (MPC) the operator requirements have undergone change. This has been manifested in terms of specification, locational and size requirements. The number of screens and overall floorspace has increased from an average of six to eight to larger complexes with 15 or more screens (for example, Star City, Birmingham has 30 screens), offering the customer not only a wider choice but reduced waiting times. In terms of their structure change has also occurred. The early MPCs tended to be 'flat floor' constructed within a standard leisure 'box', but the moves to increase density, consequent to tighter planning constraints, have led to stadium seating forming a structural element within the building. Additionally, as the impact of the shift in planning policy works through into built schemes, so the MPC has often become an integral part of a larger structure ${ }^{32}$ and may be sited at first-floor level above retail provision. ${ }^{33}$

Not all cinemas within the UK are multiplex; indeed it has been estimated $^{34}$ that only one-third are MPCs. However, they control two-thirds of all admissions and this proportion is unlikely to decrease. ${ }^{35}$ Additionally, it is the MPCs that have tended to provide the better-fitted and more quality-driven environments, ${ }^{36}$ compatible with societal trends. This also means the adoption of new technologies, for example, DVD and digital projection, as they become available, ${ }^{37}$ and with this comes a need for physical adaptation. ${ }^{38}$ The costs of fitting out an MPC, which now has an average floor area of some 4,500 square metres, ${ }^{39}$ frequently exceeds $£ 1 \mathrm{~m}$ (interview research). Arguably this could lead to tenants requiring long leases in order to amortise capital cost, but the speed of technological change and the consequently short refurbishment cycle provide counter-argument.

The growth of cinema screens and admissions has taken place over a decade and a half, but, as illustrated below, over the last five years the rate of growth has slowed such that there is a suggestion that an imbalance is occurring. Indeed, the creation of 245 additional cinema screens in the UK since 1995 has not been matched by a similar increase in admissions (Figure 1). Until 1997 there were increased admissions, but from then on admissions have declined. Whether this is due to an underlying trend or a temporary lack of good cinema product is open to debate. Dodona ${ }^{40}$ claims 


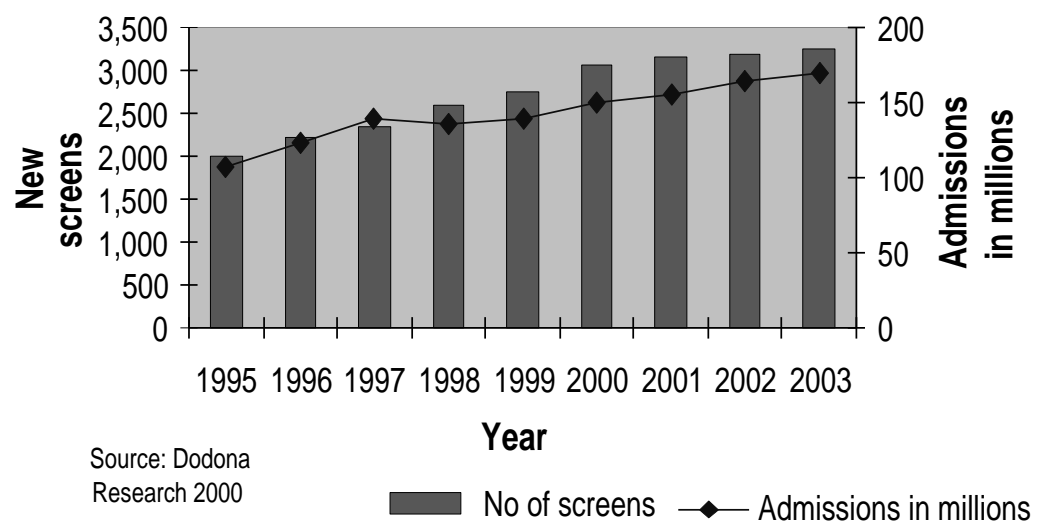

Figure 1: Actual and estimated new screens and admissions

\section{Changing specification, rapid obsolescence}

that the reduced admissions is offset by greater ticket price linked to higher-quality environments, a point also made by King Sturge. ${ }^{41}$ Armstrong highlights the transient nature of the required specification. He argues that the 'popcorn' era is being replaced by more sophisticated food fare as operators seek to provide the timepoor and money-rich society with 'the best possible experience'. ${ }^{42}$

This change in specification of an 'acceptable' leisure product is associated with some older multiplexes closing. ${ }^{43}$ Given that none is older than 15 years, there must be an implication for the nature of lease being granted.

Table 1 indicates a 2 per cent decline in admissions in 1998 and a slow estimated growth rate thereafter. This contrasts with the overall supply of cinema screens, which in 2000 alone is estimated to increase by 10 per cent. ${ }^{44}$

If admissions are expected to increase slowly then the continued increase in new screens ${ }^{45}$ will reduce admissions per screen and hence operators' profits. Already it is estimated that many independent operators, who lack the ability to offer 'blockbusters' flexibly, are working at revenue $\operatorname{losses}^{46}$ and some MPC operators

Table I: Growth in cinema supply: Actual and estimated

\begin{tabular}{lrrrr}
\hline Year & $\begin{array}{c}\text { No of } \\
\text { screens }\end{array}$ & $\begin{array}{c}\text { \% increase } \\
\text { per annum }\end{array}$ & $\begin{array}{c}\text { Admissions } \\
\text { in millions }\end{array}$ & $\begin{array}{c}\text { \% increase } \\
\text { per annum }\end{array}$ \\
\hline 1995 & 2,005 & 1.83 & 108.0 & - \\
1996 & 2,222 & 10.82 & 124.0 & 14.81 \\
1997 & 2,349 & 5.72 & 139.5 & 12.50 \\
1998 & 2,581 & 9.88 & 135.5 & -2.87 \\
1999 & 2,758 & 6.86 & 139.5 & 2.95 \\
2000 & 3,050 & 10.59 & 150.0 & 7.53 \\
2001 & 3,150 & 3.28 & 155.0 & 3.33 \\
2002 & 3,200 & 1.59 & 165.0 & 6.45 \\
2003 & 3,250 & 1.56 & 170.0 & 3.03 \\
Total \% change & 62 & & 57 & \\
\hline
\end{tabular}

Source: Dodona Research 2000 


\section{Economic sustainability?}

\section{Effect of corporate takeovers}

\section{Relating rental growth and performance}

have reported losses. If the UK has reached saturation point then, even assuming a consistent and acceptable flow of film product, where there are competing schemes the issue of fashion obsolescence may react against the older MPCs, ${ }^{47}$ leading to a lack of economic sustainability. ${ }^{48}$ The choice for some operators will be to acquire competing companies, such as is evidenced by Paramount Pictures' acquisition of a stake in United Cinema International, or by a retreat from the UK market as Hoyts have already done. ${ }^{49}$

This pessimistic vision is shared by Jones Lang La Salle. ${ }^{50}$ They question the viability of a further $£ 1.75 \mathrm{bn}$ of cinema investment to add to the $£ 1.75 \mathrm{bn}$ already invested in MPC anchors. Further, it is suggested that either operators would consolidate or look outside the UK, as is now evidenced. ${ }^{51}$ A question of sustainability thus arises.

Although the rate of increase in supply is reducing and planning guidelines are restricting the development of out-of-town multiplexes, this has been argued to be insufficient to counter the fall in admissions, estimated to have been 4 million in $1998 .{ }^{52}$

Finally, of relevance to this paper, is the declining number of MPC operators who are active within the UK. A spate of welldocumented corporate moves - for example, Cinven’s $£ 280 \mathrm{~m}$ acquisition of Odeon from the Rank Group ${ }^{53}$ — has reduced still further the already small pool of potential MPC tenants, as highlighted in the previous paper. ${ }^{54}$

The property-related issues raised by the rapid evolution in MPCs centre around the:

- speed with which specification requirements change and the speed of value obsolescence;

- ability to re-fit under the terms of the lease;

- period over which any one operator or operation can maintain viability, and hence the effect of escalator clauses;

- increasingly small number of operators who are potential tenants;

- ways, if any, that alternative uses can be 'written in' to lease agreements.

\section{METHODOLOGY}

The objectives of the research were to track rental growth in the cinema market and relate this to overall performance and to the wider economy, thereby establishing information to highlight issues for property professionals in relation to both rent review and valuation.

In order to do so, evidence of rent review performance was sought from practitioners and operators by questionnaire. This yielded very little information, with the response rate being too low to justify meaningful analysis. The reasons for the lack of response highlighted several possibilities. It could have been that: 


\section{Reviews under debate}

\section{Underlying trends to support rent reviews}

- reviews were not yet due, although data already to hand would deny this;

- information was sensitive, which might imply that there were a number of contentious issues under debate;

- reviews had not been activated, with landlords seeking to rely on the ratchets contained in the leases.

Accordingly, a series of telephone interviews were conducted with experts in the field and their consolidated views are included throughout the remainder of the paper. The interviews confirmed the suppositions that some reviews had not been activated but those that had been were, in several cases, giving rise to fundamental debate. Much of the detailed information was given in confidence, and for this reason it is inappropriate that individual attribution be given to the views expressed. A summary of the main issues arising from the interviews is given in Table 2.

Additionally, economic data (GDP and household spending data) were collated and analysed together with data on the growth of cinema supply to confirm or refute the expressed concerns about underlying profitability (Figure 2). The economic and supply data are considered alongside information on rental values. This has been compiled on a longitudinal basis looking back over seven years, which approximates to the time that the concept of the multiplex was becoming established.

The intention of the paper is to examine the underlying trends, not individual deals. To determine rental values over the study period two main sources were used. First, information on current rental values was taken from market sources. Historic levels of rental value were established by reference to rateable values, crosschecked to actual rents where available either from the literature search or from the research interviews. Such a technique enabled the establishment of a 'tone' of values for both 1993 and 1998. ${ }^{55}$ This was then combined with market data to provide a time series of rental performance. The technique of using rateable values as surrogates for market rents at the antecedent valuation dates (AVDs) has proved useful in a previous investigation ${ }^{56}$ as a means of establishing relationships between rents and the wider economy.

Table 2: Values and valuation issues revealed by interview

\begin{tabular}{|c|c|c|c|c|c|c|}
\hline \multirow{2}{*}{$\begin{array}{l}\text { Experience of } \\
\text { rent reviews } \\
40 \% \text { have experience } \\
\text { of reviews }\end{array}$} & \multicolumn{2}{|c|}{$\begin{array}{l}\text { Estimated } \\
\text { OMRV London } \\
\left(£ \mathrm{pm}^{2}\right)\end{array}$} & \multicolumn{2}{|c|}{$\begin{array}{l}\text { Estimated } \\
\text { OMRV provincial } \\
\left(£ \mathrm{pm}^{2}\right)\end{array}$} & \multicolumn{2}{|c|}{ Issues affecting deals and reviews } \\
\hline & $<120$ & $20 \%$ & $<100$ & $10 \%$ & Fit-out and/or reverse premium & 60 \\
\hline \multirow[t]{5}{*}{$60 \%$ do not } & \multicolumn{2}{|c|}{$>120<140: 30 \%$} & $>100<120$ & $60 \%$ & $\begin{array}{l}\text { Lack of comparables and analysis } \\
\text { (eg measurement, discounts) }\end{array}$ & 50 \\
\hline & $>140:$ & $30 \%$ & $>120:$ & $10 \%$ & Specification & 40 \\
\hline & \multirow[t]{3}{*}{ no view: } & \multirow[t]{3}{*}{$20 \%$} & \multirow[t]{3}{*}{ no view: } & \multirow[t]{3}{*}{$20 \%$} & Lack of tenant demand & 30 \\
\hline & & & & & Ability to pay not reflected & 20 \\
\hline & & & & & Other lease term: & 20 \\
\hline
\end{tabular}




\section{Consumer spending up $24 \%$ over 5 years}

\section{Leisure outstrips expenditure growth}

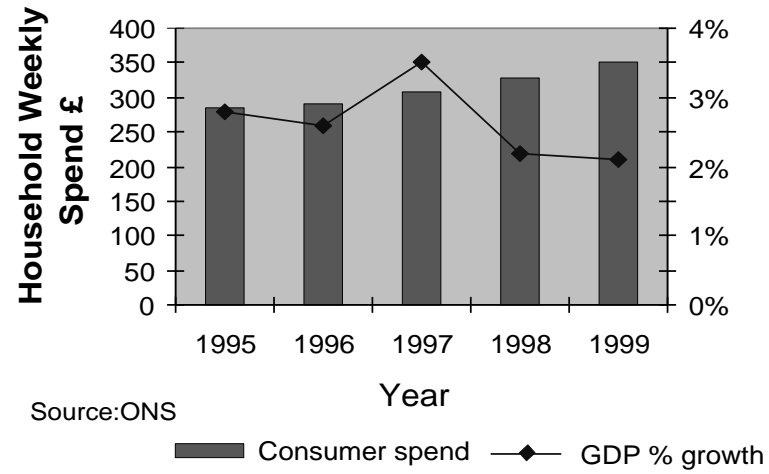

Figure 2: Consumer spending and GDP

It is accepted that the rateable value data could be argued to be inaccurate at this level of detail, but the analysis is undertaken to investigate trends only. The data were compiled in relation to some 41 MPCs, which constitute approximately 21 per cent of UK stock as at December 1999. The results thus revealed are debated, in the light of the interviews, to inform views on the performance to date and to reveal the long-term issues facing property professionals concerned with MPCs in the future.

\section{RESULTS}

\section{Growth in consumer spend to support MPC rents}

Analysis of ONS (Office for National Statistics) data ${ }^{57}$ demonstrates that consumer spending rose by approximately 24 per cent over the period from 1995 to 1999. The figures contrast with a fall in the rate of growth in GDP by nearly 2 per cent since 1997.

If the spending figures are taken to the next level of analysis (Table 3), it can be seen that while all household weekly consumer expenditure has increased between 1995 to 1999 by 24 per cent, the percentage spent on leisure services has outstripped general expenditure growth. Over the same period the percentage of

Table 3: Household expenditure by gross income

\begin{tabular}{llllll}
\hline \multicolumn{5}{c}{ Average weekly household expenditure ( $\boldsymbol{\epsilon})$} \\
\hline Year & $\begin{array}{l}\text { All } \\
\text { consumer } \\
\text { spend } \boldsymbol{\epsilon}\end{array}$ & $\begin{array}{l}\text { Leisure } \\
\text { spend } \boldsymbol{\epsilon}\end{array}$ & $\begin{array}{l}\text { \% of } \\
\text { consumer } \\
\text { spend }\end{array}$ & $\begin{array}{l}\text { Cinema } \\
\text { spend } \boldsymbol{\epsilon}\end{array}$ & $\begin{array}{l}\text { \% of } \\
\text { leisure } \\
\text { spend }\end{array}$ \\
\hline 1995 & 284.58 & 31.20 & 10.96 & 0.84 & 2.692 \\
1996 & 289.86 & 32.05 & 11.06 & 0.88 & 2.746 \\
1997 & 309.09 & 33.95 & 10.98 & 0.87 & 2.563 \\
1998 & 328.80 & 38.80 & 11.80 & 1.00 & 2.577 \\
1999 & 352.20 & 41.90 & 11.90 & 1.00 & 2.387 \\
$\%$ change & $24 \%$ & $34 \%$ & & $19 \%$ & \\
\hline
\end{tabular}

Source: ONS Family Spending 


\section{Is leisure expenditure growth sustainable?}

Few settlements on rent reviews household budgets devoted to leisure rose by almost a full percentage point from 10.96 per cent to 11.90 per cent.

During the analysis period household expenditure on leisure services increased from $£ 31$ in 1995 to $£ 41$ in 1999 , an increase of 34 per cent, which is ahead of that for all consumer expenditure over the same period. The question arises as to whether this rise in leisure expenditure is sustainable when there is evidence of slower growth in GDP (See Table 3). However, although expenditure on leisure has grown, the percentage that is spent on cinema going has decreased from 2.7 per cent in 1995 to 2.4 per cent in 1999.

In absolute terms, spending on cinema admissions has remained flat, but clearly from the analysis, and given that the average tariff has edged up to reflect higher-quality technology and environments, cinema attendance has not kept pace with the percentage change in leisure spend. Further analysis would indicate that this falling off has been counterbalanced by increased expenditure on health and fitness rather than on other forms of passive entertainment.

Figure 3 shows that despite the significant rise in household expenditure on cinema going from 1997 (87p) to 1998 (£1), this actually represents a fall in the percentage of leisure spend. This rise in weekly household expenditure could be explained by households choosing to pay more for a visit to an expensive quality multiplex than paying for a cheaper cinema. However, the fall in percentage of funds spent on cinema going is a cause for concern if the leases under which operators hold cinemas have built-in rental increases in the order of 3 per cent per annum compound - at least for the first two review periods.

\section{Rental trends for MPCs}

The research revealed that very few rent review settlements have taken place despite the fact that data collected on $91 \mathrm{UK}$ multiplexes indicate that 54 per cent of those opened in 1995-96 or

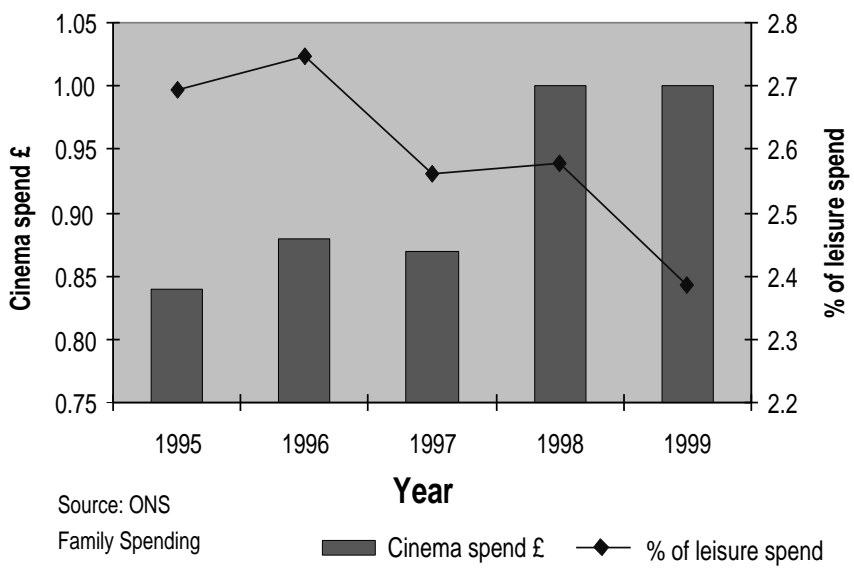

Figure 3: Cinema spending 


\section{Assessing trends by rateable value}

\section{Cinema rentals levels rose by $79 \%$ in $1993-$ 1998}

\section{Rental values have fallen back}

earlier. ${ }^{58}$ Therefore it was not possible to calculate actual rental growth related to individual properties. Unlike the main bulk classes of investment property, the data in the Investment Property Databank (IPD) records is also insufficient to draw conclusions in any meaningful way. Accordingly, the research investigated the level of rents achievable today together with those established via the rating lists in order to estimate average levels of rental growth over a seven-year period. Even adopting this approach, rental evidence based on recent lettings was scarce as many of the new developments have been let on forward-funded deals with rents agreed up to two years ago.

Rental values per square metre were established for 2000, 1998 and 1993. The 2000 figures were estimated following interviews with numerous agents. The 1993 and 1998 figures were calculated by combining the published rateable values for 1995 and 2000 with the known floor areas to give a figure per metre squared.

The analysis demonstrates that between 1993 and 1998 there was a substantial rise in cinema rentals from an estimated $£ 78$ per square metre average to some $£ 140$, based on the Valuation Office data. This represents an overall increase of 79 per cent. Over five years it equates to an annual rise of 12.41 per cent. However, rental values have fallen back according to valuer opinion, with some valuers indicating significant falls over the levels of two years ago. Those valuers who have an optimistic outlook suggested levels of up to $£ 130$ for provincial cinemas; others considered the current OMRV to be closer to $£ 100$ per square metre. The implications of these opinions are reflected in the analysis below.

Two scenarios were selected to reflect an optimistic situation and a pessimistic one. The first scenario $\mathrm{A}$ is an optimistic situation as shown in Table 4, where an average rent of $£ 130$ per square metre for multiplexes was taken for 2000. This would indicate that since 1998 rents have fallen at a rate of 7 per cent, which represents an annual decrease of 3.64 per cent.

Scenario B shows the pessimistic situation where multiplex rentals have actually fallen to as low as $£ 100$ per square metre. This

\begin{tabular}{|c|c|c|c|}
\hline & Average 1993 & $\begin{array}{l}\text { Scenario A } \\
\text { Average } 1998\end{array}$ & $\begin{array}{l}\text { Optimistic } \\
\text { average } 2000\end{array}$ \\
\hline$E$ per sq $\mathrm{m}$ & 78 & 140 & 130 \\
\hline$\%$ change & & $79 \%$ & $-7 \%$ \\
\hline \multirow[t]{3}{*}{$\%$ change per annum } & & $12.41 \%$ & $-3.64 \%$ \\
\hline & & Scenario B & \\
\hline & Average 1993 & Average 1998 & $\begin{array}{l}\text { Pessimistic } \\
\text { average } 2000\end{array}$ \\
\hline$E$ per sq $\mathrm{m}$ & 78 & 140 & 100 \\
\hline$\%$ change & & $79 \%$ & $-29 \%$ \\
\hline$\%$ change per annum & & $12.41 \%$ & $-15.48 \%$ \\
\hline
\end{tabular}


'Many MPCs are over-
rented'

'yields could be expected to rise'
Table 5: Annual rental growth comparison: Cinemas and retail

\begin{tabular}{lllll}
\hline $\begin{array}{l}\text { Cinemas } \\
\text { 1993-1998 }\end{array}$ & $\begin{array}{l}\text { Retail } \\
\mathbf{1 9 9 3 - 1 9 9 8}\end{array}$ & $\begin{array}{l}\text { Cinemas } \\
\text { (pessimistic) } \\
\mathbf{1 9 9 8 - 2 0 0 0}\end{array}$ & $\begin{array}{l}\text { Cinemas } \\
\text { (optimistic) } \\
\mathbf{1 9 9 8 - 2 0 0 0}\end{array}$ & $\begin{array}{l}\text { Retail } \\
\mathbf{1 9 9 8 - 2 0 0 0}\end{array}$ \\
\hline $12.41 \%$ & $4.20 \%$ & $-15.48 \%$ & $-3.64 \%$ & $5.5 \%$ \\
\hline
\end{tabular}

Source: Insignia Richard Ellis, IPD 2000

not only represents a fall of 29 per cent over two years but also an annual decrease of over 15 per cent.

The analysis suggests that many MPCs where the lease agreement was dated between 1996 and 1998 are already overrented. For those with rents fixed prior to that date and where escalators have been activated a similar situation may have arisen. In the light of the analysis it would appear that many cinema investments are rapidly becoming bond-style in their characteristics, and this could be expected to work through to the pattern of yields.

Before yields are examined a comparison of rental growth between cinemas and retail units was undertaken using data from Insignia Richard Ellis ${ }^{59}$ and IPD. ${ }^{60}$ The results are shown in Table 5 . They indicate that whereas annual rental growth for cinemas for the period 1993-1998 far outstripped retail, the reverse has been the case over the last two years - even if the most optimistic scenario is taken. This would suggest that if investors are acting rationally, and especially given the supply scenario, the yields for cinemas should demonstrate an inverse relationship to that observed for retail units. This is considered below.

\section{Change in yields}

Figure 4 shows the pattern of yields for cinemas since 1993. It can be seen that yields have consistently fallen to a lowest point of 6.25 per cent in 1999. In 1993 there was virtually no institutional market

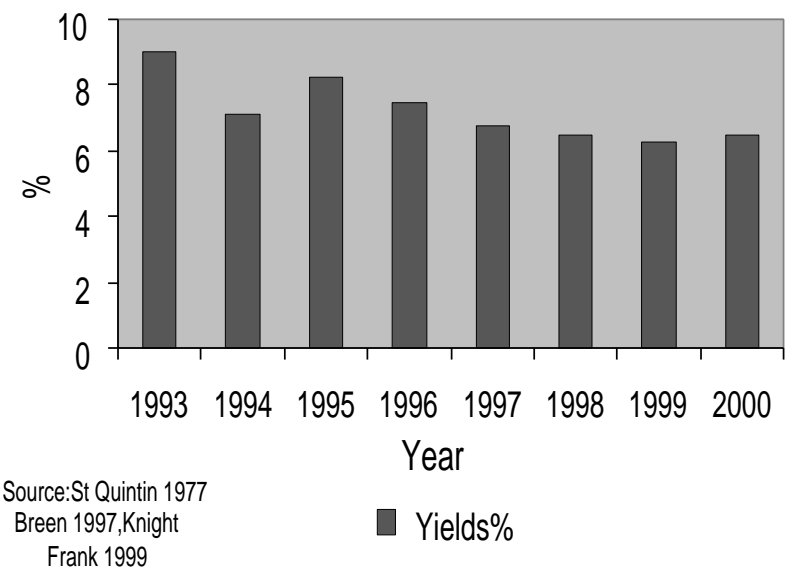

Figure 4: Cinema yields 


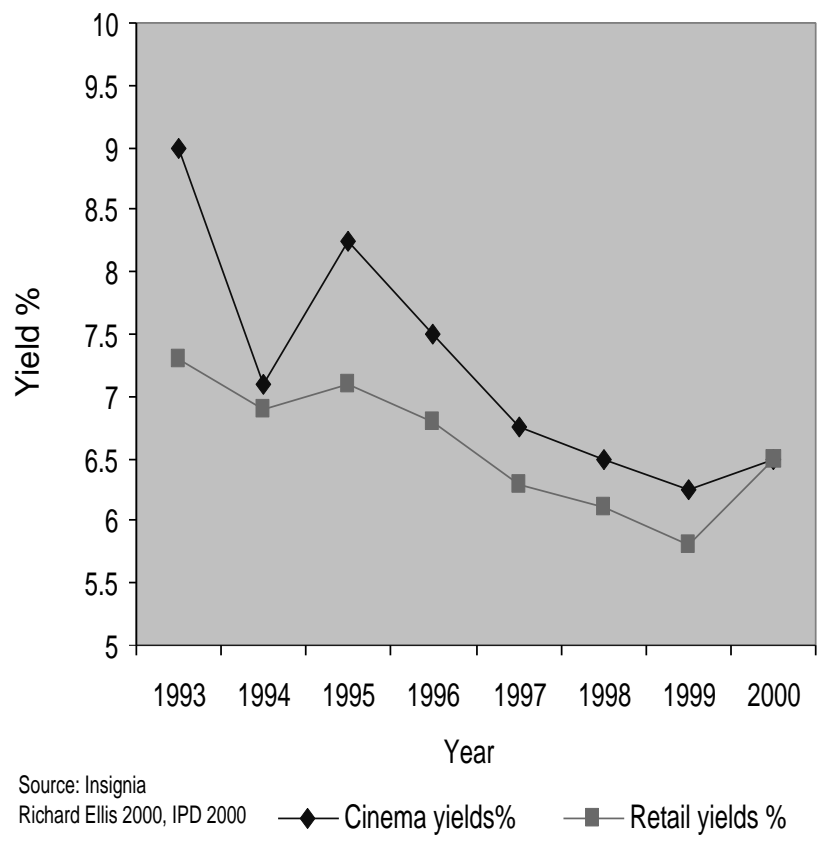

Figure 5: Comparison of cinema and retail yields

Yield convergence with retail in leisure properties, with a lack of product and no statistical measures to provide confidence. Consequently, yield information is dubious at best. Since then, participation has increased and over the last three years the volume of transactions has been sufficient to enable yields to be distilled from the deals affected. Figure 5 tracks the movement of yields for all leisure properties. It has not been possible to isolate cinemas as these have frequently formed part of deals for leisure complexes.

Figure 4 and Table 5 show that, just at the time that cinema rental growth slowed or reversed, yields have dropped - implying the presence of continued rental growth. Additionally, when the yields are shown alongside retail yields (Figure 5) a pattern of yield convergence emerges. Both retail and cinema yields have fallen since 1994, but whereas retail yields are reported to have moved upwards, despite rental growth in excess of 5 per cent, those for cinemas have not shown a similar trend in the face of adverse rental conditions. The caveat, however, lies in the limited volume of data from which to draw inferences. There is some evidence to suggest that a yield differential between in-town and out-of-town leisure schemes began to develop in 1998 with the trend to develop in town. However, the evidence is based on few transactions and could be said to relate to the more up-to-date specification of in-town schemes rather than any investor preference in terms of location.

\section{Current lettings and reviews}

Table 2 contains a summary of views in relation to both rental evidence and matters that are important in achieving lettings and agreeing rent reviews. The majority view is that there are currently 


\section{Rental distortion}

\section{A lack of standard measurement code}

\section{Quoted yields under question}

few settled transactions, therefore all the evidence has to be dealt with cautiously. In particular, the issue of face rents and effective rents is distorting the headline figures, with landlords paying tenants that amount to reverse premiums to cover the costs of fitting out. The interviews also pointed to a discrepancy in the methods of measurement used to analyse rents - perhaps not surprising given that the RICS's standard measurement code ${ }^{61}$ does not prescribe best practice for leisure units - and in the changes in specification in units that have taken place. Most interviewees confirmed that landlords were still insistent upon the insertion of escalator clauses for at least the first rent reviews, perhaps showing a continued concern about performance. Some also indicated that landlords were seeking to insert keep-open clauses applicable for a minimum of five years. Even this length of guaranteed trading is being resisted by some operators.

The implications of these findings and their effect on investment performance and impending rent reviews are now considered.

\section{ISSUES ARISING An over-rented market?}

The analysis above shows that an over-rented situation has arisen for many MPCs. The rapid growth in rental values has reversed, how dramatically depending upon which scenario in relation to current market conditions is taken. This is hardly surprising given the slowdown in the growth in cinema admissions combined with the increase in supply, which has affected underlying profitability. With leisure trading properties, more than most other commercial properties, the value to the tenant lies in the inherent profitability of the business. ${ }^{62}$ The over-rented situation has been compounded by a shift away from rents determined in relation to the profits method and the adoption of the comparables approach based on analysis by size and the adoption of ratcheted rents.

It is argued that the evidence in relation to rents has rendered the quoted yields for MPCs inappropriate in terms of providing an internal rate of return compatible with the long-term requirements of investors. As stated above, institutional investor return requirements are quoted ${ }^{63}$ as a return from leisure investments of just under 10 per cent for leisure parks and fractionally less (9.75 per cent) for in-town leisure schemes. This means that, for investor expectations to be met, positive rental growth in the order of 4 per cent per annum is required. If rental values have fallen in the manner estimated by some experts, then not only has an overrented situation already occurred, but it is likely to be compounded as more units move towards next review. Descriptions of the cinema market being in 'free fall' may be exaggerated, but the evidence of new lettings is thin. Where deals are being agreed, the use of confidential side deals is prevalent (primary research), which in turn makes the preparation of capital values difficult due to distortions in comparable evidence. 


\section{Returns in the mid 19905 were positive}

\section{An analysis of performance}

Attached as an Appendix are a series of valuations based on a hypothetical MPC of a fairly typical specification located in a good provincial town in southern England. Two scenarios are given (Scenario X and Scenario Y). The basic method used is based on that demonstrated by Walker. ${ }^{64}$

Scenario $\mathbf{X}$ is based on a hypothetical letting effected some five years ago, for a term of 25 years with five-yearly upward-only rent reviews and 3 per cent escalators for the first two reviews. Three valuations have been carried out, in 1995, 1998 and 2000. The rental values for 1995 and 1998 are taken from market data. Two estimates for 2000 have been taken - one 'pessimistic' and one 'optimistic'. In each case valuations have been prepared using both hardcore and equated yield (shorthand DCF) methods. In the optimistic scenario the escalators were not activated, but with the pessimistic they were. The summary results are shown in Table 6 . An investigation of the returns that they reveal (Table 7) shows that over the first three years of the holding period the annual return was 28 per cent, which is very positive. Over the last two years the situation has changed dramatically, with the return being between 3 per cent for the optimistic view and as low as -5 per cent for the

Table 6: Summary of freehold valuation of MPCs, 1995-2000

\begin{tabular}{|c|c|c|c|c|c|}
\hline \multicolumn{6}{|l|}{ Scenario $X$} \\
\hline & 1995 & 1998 & 2000 & $\begin{array}{l}\% \text { annual increase } \\
\text { over } 5 \text { years }\end{array}$ & $\begin{array}{l}\% \text { annual change } \\
\text { from 1998-2000 }\end{array}$ \\
\hline \multicolumn{6}{|l|}{ Hardcore approach } \\
\hline Optimistic Capital value & $£ 5,669,538$ & $\notin 9,813,596$ & $€ 9,448,052$ & 10.75 & -1.88 \\
\hline Pessimistic Capital value & - & - & $£ 7,989,196$ & 7.10 & -9.77 \\
\hline \multicolumn{6}{|l|}{ Equated yield approach } \\
\hline Optimistic Capital value & $£ 5,669,538$ & $\notin 9,896,352$ & $£ 9,448,052$ & 10.75 & -2.29 \\
\hline Pessimistic Capital value & - & - & $£ 7,502,039$ & 5.76 & -12.93 \\
\hline $\begin{array}{l}\% \text { change between } \\
\text { methods }\end{array}$ & $0.00 \%$ & $0.84 \%$ & $\begin{array}{l}0.00 \% \\
-6.49 \%\end{array}$ & & \\
\hline
\end{tabular}

Table 7: Rates of return

\begin{tabular}{llll}
\hline Scenario X & \multicolumn{3}{c}{ IRR analysis } \\
\hline & $\begin{array}{l}\text { I995-2000 } \\
\%\end{array}$ & $\begin{array}{l}\mathbf{1 9 9 5 - 1 9 9 8} \\
\%\end{array}$ & $\begin{array}{l}\mathbf{1 9 9 8 - 2 0 0 0} \\
\%\end{array}$ \\
& & & \\
\hline Hardcore approach & 18 & 28 & 3 \\
Optimistic & 15 & 28 & -2 \\
Pessimistic & 18 & & \\
Equated yield approach & 28 & 3 \\
Optimistic & 13 & 28 & -5 \\
Pessimistic & & & \\
\hline
\end{tabular}




\section{A dramatic change}

\section{A lag on retail returns}

\section{A need to increase risk premia}

pessimistic. Over the full five-year period the internal rate of return (IRR) was in the order of 13-18 per cent per annum.

Scenario $\mathbf{Y}$ is based on a hypothetical letting effected some two years ago in the height of the rental boom. Again the assumption is of a 25-year letting on similar lease terms, including the escalator clause. Once more 'optimistic' and 'pessimistic' rental assessments have been made for the 2000 position and valuations have been carried out using both hardcore and equated yield techniques. However, in this case the valuations have been prepared on two assumptions: first on the basis that an escalator clause has been inserted in the lease; and secondly, on the assumption of no escalator. The results, shown in Table 8 , demonstrate just how dependent the capital value has become on the rent protection clause, with up to some $£ 2 \mathrm{~m}$ or 28 per cent of value related to it.

Return calculations were also undertaken and are shown in Table 9. If these are compared with an estimate of retail returns ${ }^{65}$ over the same period, the cinema is shown to lag behind as retail returns show figures of 13.7 per cent per annum between 1995 and 1998, 11.6 per cent per annum between 1998 and 2000 and 12.9 per cent per annum over the five-year period. Whichever scenario is assumed, the IRR for retail over the last two years has outstripped that for the MPC. This represents a reversal of the pattern for the preceding five years.

The implications for the investor are clear. Even allowing for the caution that must be placed on the figures, the current risk premium attached to leisure properties ${ }^{66}$ of some half of one percentage point appears misguided. The timing of returns has not matched yield movements. Further, given the implications on both the supply and demand sides of the valuation equation, the current yield patterns may be hard to sustain and this places further pressure on returns. However, the presence of the escalator clauses has undoubtedly acted as a protection to investment values, in that

Table 8: Summary of freehold valuation of MPCs let in 1998

\begin{tabular}{|c|c|c|c|c|}
\hline \multicolumn{5}{|l|}{ Scenario $\mathbf{Y}$} \\
\hline $\begin{array}{l}\text { Capital value } \\
2000\end{array}$ & $\begin{array}{l}\text { Optimistic with } \\
\text { escalator }\end{array}$ & $\begin{array}{l}\text { Optimistic without } \\
\text { escalator }\end{array}$ & $\begin{array}{l}\text { Pessimistic with } \\
\text { escalator }\end{array}$ & $\begin{array}{l}\text { Pessimistic } \\
\text { without } \\
\text { escalator }\end{array}$ \\
\hline Hardcore & $£ 10,698,418$ & $£ 9,481,724$ & $£ 9,690,355$ & $£ 8,536,572$ \\
\hline Equated yield & $£ 9,669,838$ & $£ 9,597,479$ & $£ 9,108,431$ & $£ 8,198,082$ \\
\hline
\end{tabular}

Table 9: Rates of return

IRR Analysis

\begin{tabular}{lll} 
Scenario $\mathbf{Y}$ & & \\
\hline I998-2000 & $\begin{array}{l}\text { Optimistic with escalator } \\
\%\end{array}$ & $\begin{array}{l}\text { Pessimistic with escalator } \\
\%\end{array}$ \\
\hline Hardcore & 11 & 7 \\
Equated yield & 8 & 5
\end{tabular}




\section{Ratchet reviews may be relied upon}

The problem of fit-out estimated drops in rental value of up to 30 per cent have not led to double-figure decreases in capital values.

\section{Issues for impending rent reviews}

Little evidence of rent review settlements was found, although it is known that a few reviews have moved to third-party determination. For those units whose rent review clauses are linked to built-in escalators, the open market evidence to support increases over and above those resulting from implementation of the ratchet is simply not there. Hence the supposition is that many will rely on the builtin protection clauses. Therefore it could be argued that there are no issues for rent reviews - and that might be the case. However, the leases typically only have an escalator for the first two reviews, and some newer lettings for only one. So, given that the lease lengths are on average 25 years minimum, it seems likely that they will come forward for open market review. The arguments that are emerging will then be debated either in negotiation or through disputes procedure.

\section{Fit-out and/or reverse premium}

Many of the surveyors interviewed raised the issue of fit-out costs. MPCs, like many leisure units, are normally let on a shell basis with the tenant being responsible for fitting out at their own expense. For MPCs this can be a very significant cost and one which, if borne by the tenant, may currently render the operation non-viable. Therefore the practice has grown for the landlord to pay for such costs in order to protect the 'headline' rental figure. But the debatable issue is whether they are in the nature of a contribution to fit-out or effectively a reverse premium. If the landlord pays, should the cost be annualised and then deducted from the agreed rent to arrive at a true effective rent? If this is so, then even the rents quoted as achievable today may overstate the actual situation.

Alternatively, if the landlord has borne the cost, fit-out could be argued to be part of the value of the freehold. In this case the question arises as to whether the costs are to be included in the rental calculation at review - and of course there may be little evidence for fully fitted cinemas, especially if the fittings are by then semi-obsolete. The issues of both headline versus effective rents and of treatment of fittings have proved contentious within the field of rent review (see for example, the disputes in Broadgate Square Plc v Lehman Bros Ltd, 1995 [01 EG 111] and Ocean Accident \& Guarantee Corporation v Next Plc, 1996 [EGCS 187]). Their application to the MPC scenario is likely to be equally contentious.

\section{Lack of comparables}

Despite the growth in MPCs they are still very limited in number and geographically disparate. As their underlying value, just as 


\section{A problem of comparables}

Tenant covenant

\section{Rapidly changing occupational requirements}

with most commercial leisure properties, relates closely to demographics, the use of comparables from other towns and regions may be difficult to apply. This is a factor that investors have long appreciated ${ }^{67}$ but in the sudden rush to move into the leisure market it appears to have been overlooked. This lapse of collective memory might be regretted. Another difficulty, and one that was highlighted by several respondents, relates to the physical measurement of MPCs. Whereas there exists a standard method of measurement for most commercial property, it does not apply to leisure units. This was clearly demonstrated by respondents, several of whom quoted the same letting - but for which the rent achieved per metre squared varied considerably from valuer to valuer, depending on which approach to measurement had been adopted!

\section{Specification}

This paper has already highlighted the rapid changes in the specification of MPCs that has occurred over a very short time span. This raises three valuation issues:

- For how long will a 'prime' multiplex stay prime, and what are the consequences when a newer format becomes the desired industry norm? In particular, if a calculation of worth ${ }^{68}$ is undertaken how should this be reflected in the choice of exit yield?

- What is the rate of rental allowance that should be made for cinemas that are, for example, sited at first-floor level, and for those of exceptionally large or small floor area?

- How can a valuation be carried out if a unit is economically and physically obsolete a decade or more before the end of the lease?

The last point is equally a management issue, but it has implications for tenant and landlord alike. The authors do not suggest that they have the answers to the questions, but in terms of future performance they are critical.

\section{Lack of tenant demand}

Both Sayce $^{69}$ and Hughes ${ }^{70}$ highlighted the issue of tenant covenant and questioned whether there were enough strong covenants to support the leisure investment sector. Others foresaw the issue of withdrawal of interest in the UK market by some tenants. ${ }^{71}$ Since then the take-over of Odeon by Cinven, the withdrawal of Hoyts and the sale of Virgin Cinemas have all added weight to these concerns. Depending on the exact wording of the rent review clause, it is to be expected that there will be a presumption of a willing lessee, but what that willing lessee will be deemed to be willing to pay could become questionable! The matter has been debated within the courts in other contexts; it might be an issue as far as the MPC is concerned. 


\section{A risk of default}

\section{Keep-open clauses}

\section{Ability to pay}

The original purpose of a rent review clause was to enable any changes in value, consequent to either inflation or external value drivers, to be reflected in the rent paid by the tenant. With the adoption of upward-only clauses as standard in the UK commercial property markets, as argued by, for example, Hillson, ${ }^{72}$ the rent review serves only to protect the landlords' interests and enable them to take part in any real or inflationary rental growth. In this way the UK markets have developed independently and differently from most other commercial property markets.

However, if too large a discrepancy between the level of rents achievable on a new letting and the rent fixed under an upwardsonly rent review and/or ratchet occurs, the ultimate loss is also suffered by the landlord. This was vividly illustrated in Scott's analysis $^{73}$ of the London office market some ten years ago, where landlords suffered in terms of both lack of saleability of their interest and capital loss due to rising yield profiles. If the pattern revealed by the above analysis for MPCs continues, such risks are likely to apply. But, arguably, the situation is worse, as the effect of the escalator clauses requires the tenants to pay rents that are rising faster than inflation. In the office market at least this did not happen, although the level of over-rentedness persisted for nearly ten years and in some cases still persists.

\section{Other lease terms}

During the interviews two other clauses were singled out as potentially presenting difficulties in terms of settling rent reviews or indeed in asset management terms. These were the alienation clause and the keep-open clause. The former, it is understood, is normally written in on a standard commercial lease clause. For leases that postdate 1995 this would require a lessee to guarantee the financial performance of a first assignee. Given the lack of depth of the tenant demand and the inflexibility of the more recent structures, the difficulties in finding an assignee of good financial standing could be so much as to effectively render the alienation clause inoperable.

Several valuers pointed to the inclusion of keep-open clauses under which the lessee is obliged to continue trading, whatever revenue loss may be incurred, for a specified duration. At first sight the period of operation, which was quoted as being between five and ten years, does not look harsh, but given the implications, as spelled out in the retail context in Co-operative Insurance Society $v$ Argyll Stores (Holdings) Ltd., 1997 [23 EG 137], they could present the tenant with great expense even if they proved ultimately to be unenforceable.

\section{CONCLUSIONS}

The MPC provides perhaps the most extreme example of the issues that face the valuer and manager of commercial leisure properties. 


\section{The changing nature of the leisure experience}

\author{
Investment \\ performance: a virtual \\ reality?
}

\section{A paradox caused by new lease terms}

Over the last 15 years the rate of development has been fast, but until the last two years the growth in supply was matched by rises in the number of cinema admissions. There was, therefore, a sound economic base to support the developments. Underlying profitability in the hands of the operator was sufficient to justify entering into lease agreements. The nature of those lease agreements was, to a large extent, not negotiable, except as to the initial rental deals.

However, the nature of leisure is that it is ever changing. The last decade may have experienced an explosion of developments feeding off a cinema industry emanating from the "coke-crazed brains of Hollywood producers' who have produced 'universal story-boards of global dreams - sugary and sentimental, violent and pornographic, all beautiful people and happy endings where the good guy always wins and so does the USA' ${ }^{74}$ But the Hollywood dream is always a virtual reality, and the evidence adduced in relation to the current investment performance of the UK MPC leads to the suggestion that this too is more virtual than actual.

An examination of hypothetical lettings based on average rentals demonstrates that over a seven-year period the returns to landlords have been good and have outstripped the retail sector. This in itself on face value provides an incentive to invest. However, over the last two years, during which period leisure has in many ways for the first time gained institutional acceptability, ${ }^{75}$ the situation has been reversed. The nature of the leases is acting to give landlords financial protection via the escalator clauses, but these will only provide protection if the tenant is able to sustain the rent payment.

The research indicated that the number of potential tenants and assignees has declined and this, potentially, is an issue for landlords and tenants alike. As Stephens argues 'Its star status has been slightly dented recently'. ${ }^{76}$ If the tenant cannot sustain the rent, now assessed without reference to profitability, and assignees are not there, not only might default occur but the remaining units and their investment yields will be damaged. The inflexibility of structures associated with the most modern form of MPC also presents a difficulty, for there are few alternative tenants who can make use of tiered seating. Given this, the earlier MPCs which were constructed as ground-floor boxes might yet prove more adaptable.

The paradox thrown up by the adoption of the standard leasing structure and the introduction of rents fixed by reference to floor area is that, by so doing, the relationship with the ability to pay that was a feature of leisure properties valued by the profits method has been lost. No doubt the rent review surveyors, if rents do rise to overcome the escalator clauses, will have ample grounds for debate and negotiation, but the real issue will be one of dealing with buildings whose economic life is shorter than the leases that have been constructed round their shells. The future life of the buildings, however, would appear far from certain and the lesson 


\section{A fundamental mis- match?}

that could be learnt is the fundamental mis-match that is beginning to be apparent between the rigidity of institutional needs, as manifested through the lease agreement, with the requirement for flexibility that is fundamental to the leisure industry in general, and the cinema market in particular.

\section{APPENDIX}

Scenario $X$

1995

Leisure park, edge of town, southern counties

Valuation - freehold

Date of valuation: Sept 1995

Lessee: Flix-U-Like Lessor: Improvident escalator Investors

Input

Next review date Sept 2000 Tenure Freehold CV

Rent receivable $\quad £ 445,018 \quad$ Lease start $\quad$ Sept $1995 \quad \mathfrak{£ 5 , 6 6 9 , 5 3 8}$

Lease expiry

Rent reviews

Area $\mathrm{m}^{2}$

Screen 2020

5

4,541

12

OMRV per $\mathrm{m}^{2}$

$£ 98$

OMRV pa

$£ 445,018$

scalato

Rent review 1

Rent review 2

$115.93 \%$

$134.39 \%$

All risks yield $\quad 8.25 \%$

5 years

10 years

Valuation (hardcore and equated) OMRV 


\section{Scenario $\mathrm{X}$}

1998

Leisure park, edge of town, southern counties

Valuation - freehold

Date of valuation: Sept 1998

Lessee: Flix-U-Like

Input

Next review date Sept 2000

Rent receivable

Lease expiry

Rent reviews

Area $\mathrm{m}^{2}$

Screen

OMRV per $\mathrm{m}^{2}$

OMRV pa

All risks yield

Equated yield

Growth

Lessor: Improvident Investors

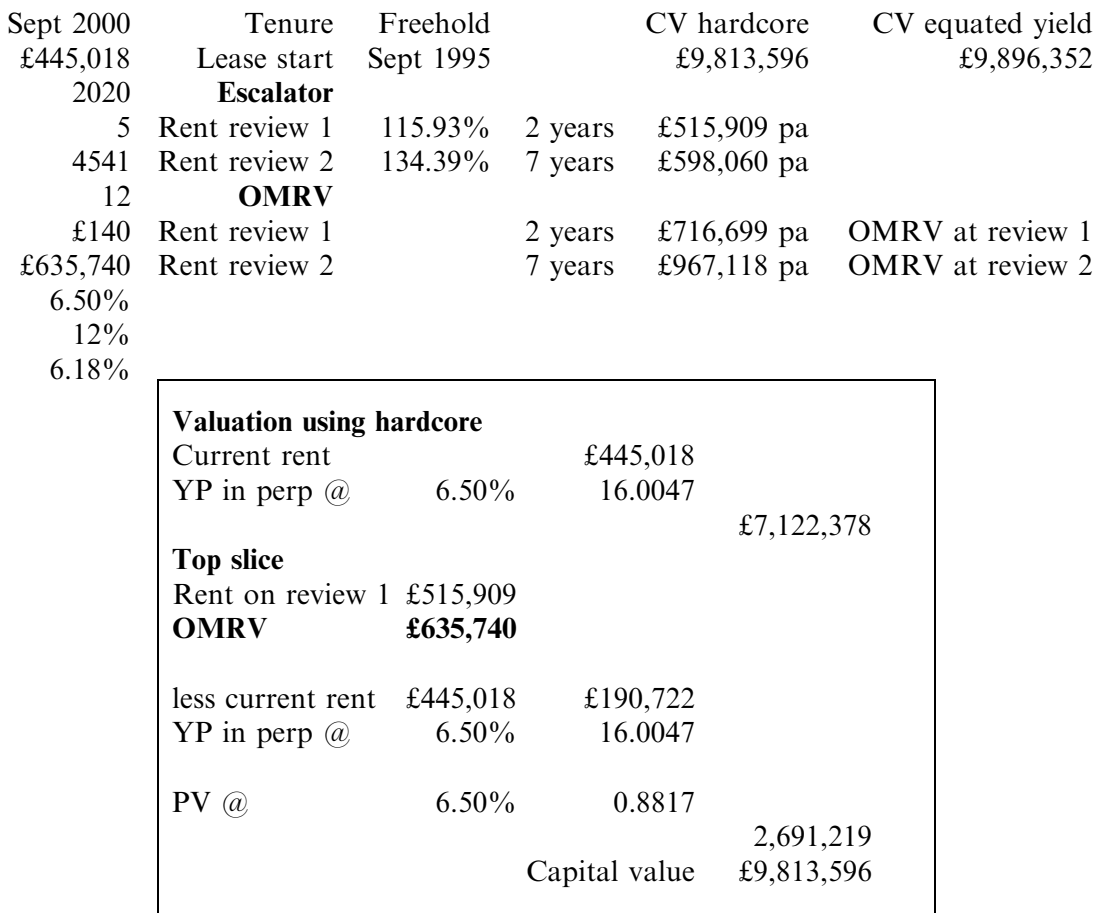

\begin{tabular}{|c|c|c|c|}
\hline \multicolumn{4}{|c|}{ Valuation using shorthand equated yield } \\
\hline Current rent & & $£ 445,018$ & \multirow[b]{3}{*}{$£ 752,103$} \\
\hline YP for term@ & $12 \%$ & 1.6901 & \\
\hline & & & \\
\hline Expected OMRV & & $£ 716,699$ & \\
\hline YP in perp@ & $6.50 \%$ & 16.0047 & \\
\hline PV for term@ & $12 \%$ & 0.7972 & \\
\hline & & tal value & $\begin{array}{r}9,144,249 \\
£ 9,896,352\end{array}$ \\
\hline
\end{tabular}




\section{Scenario $\mathrm{X}$}

2000 optimistic

Leisure park, edge of town, southern counties

Valuation - freehold

Date of valuation: Sept 2000

Lessee: Flix-U-Like

Input

Next review date $\quad 2000$

Rent receivable $\quad £ 445,018$

Lease expiry

Rent reviews

Area $\mathrm{m}^{2}$

Screen

OMRV per $\mathrm{m}^{2}$

OMRV pa

All risks yield

Equated yield

Growth

Lessor: Improvident Investors

2000
$£ 445,018$
2020
5
4,541
12
$£ 130$
$£ 590,330$
$6.50 \%$
$10 \%$
$3.95 \%$

\section{Tenure Freehold}

Escalator

Rent review $1 \quad 115.93 \% \quad 0$ years $\quad £ 515,909$

Rent review $2 \quad 134.39 \% \quad 5$ years $\quad £ 598,060$

\section{OMRV}

Rent review 1

Rent review 2

0 years

5 years

$£ 590,330$ pa

$£ 716,471$ pa

OMRV at review 1

OMRV at review 2

\begin{tabular}{|lrrr|}
\hline \multicolumn{3}{|l|}{ Valuation using hardcore } \\
Current rent \\
YP in perp @ & $6.50 \%$ & 16.0047 & \\
& & & $£ 7,122,378$ \\
Rent on review 1 & $£ 515,909$ & & \\
OMRV & $£ 590,330$ & & \\
less current rent & $£ 445,018$ & $£ 145,312$ & \\
YP in perp@ & $6.50 \%$ & 16.0047 & \\
PV @ & $6.50 \%$ & 1.0000 & \\
& & & $£, 325,674$ \\
& & & $£ 9,448,052$ \\
\hline
\end{tabular}

Valuation using shorthand equated yield

Current rent $£ 445,018$

YP for term@ 10\% $\quad 0.0000$

$£ 0$

Expected OMRV

YP in perp @

$£ 590,330$

PV for term@

$\begin{array}{rr}6.50 \% & 16.0047 \\ 10 \% & 1.0000\end{array}$

$9,448,052$

Capital value

$£ 9,448,052$ 


\section{Scenario X}

2000 pessimistic

Leisure park, edge of town, southern counties

Valuation - freehold

Date of valuation: Sept 2000

Lessee: Flix-U-Like

Lessor: Improvident Investors

\section{Input}

Next review date

Rent receivable

Sept 2000

Lease expiry

Rent reviews 2020

Area $\mathrm{m}^{2}$

Screen

OMRV per $\mathrm{m}^{2}$

OMRV pa

Equivalent yield

Equated yield

Growth

5
4541
12
$£ 100$
4,100
$.50 \%$
$10 \%$
$95 \%$

Rent review $1 \quad 115.93 \%$ 0 years

Rent review $2 \quad 134.39 \% \quad 5$ years

\section{OMRV}

Rent review 1

Rent review 2

$3.95 \%$

$$
\begin{array}{rr}
0 \text { years } & £ 454,100 \text { pa } \\
5 \text { years } & £ 551,131 \text { pa } \\
10 \text { years } & £ 668,896 \text { pa }
\end{array}
$$

CV hardcore $£ 7,989,196$

$£ 515,909$ pa

$£ 598,060$ pa

\section{With escalator}

Valuation using shorthand equated yield

OMRV

YP in perp@ 6.50\% $@ 444,100$

$£ 7,267,732$

Rent on review $1 £ 515,909$

Escalator 1

$£ 515,909$

Less OMRV

Top slice

YP for term @

$£ 454,100$

PV@

Escalator 2

£551,13

Less OMRV

Top slice

YP for term @

$$
\begin{array}{rr} 
& £ 61,809 \\
10 \% & 3.7908 \\
10 \% & 1.0000
\end{array}
$$

234,306

PV@

454,251

$£ 7,989,196$

$£ 7,989,196$
CV equated yield
$£ 7,502,039$

Escalator activated at review 1 Escalator activated at review 2 


\section{Scenario Y}

Optimistic with escalator

Leisure park, edge of town, southern counties

Valuation date: Sept 2000

Lessee: Flix-U-Like

Input

Next review date 2002

Rent receivable $£ 624,000$

$\begin{array}{lr}\text { Lease expiry } & 2023 \\ \text { Rent reviews } & 5 \\ {\text { Area } \mathrm{m}^{2}} & 4,541 \\ & \\ \text { Screen } & 12 \\ \text { OMRV per m } & \\ \text { OMRV pa } & £ 130 \\ \text { Equivalent yield } & 6.590,330 \\ \text { Equated yield } & 10 \% \\ \text { Growth } & 3.95 \%\end{array}$

Lessor: Improvident Investors

$$
\text { Tenure Freehold }
$$

CV Hardcore $£ 10,698,418$

\section{Escalator}

Rent review 1

Rent review 2

$115.93 \% \quad 2.25$ years $134.39 \% \quad 7.25$ years
$£ 723,403$ pa $£ 838,594$ pa
CV Equated yield $£ 9,969,838$

Over-rented on first review Over-rented on second review
Rent review 1

Rent review 2
2.25 years

7.25 years 12.25 years
$£ 644,083$ pa $£ 781,709$ pa $£ 948,744$ pa

\begin{tabular}{|lrrrr}
\hline \multicolumn{3}{|l}{ Valuation using hardcore } & & \\
Current rent & \multicolumn{3}{c|}{$£ 624,000$} & \\
YP in perp @ & $6.50 \%$ & 16.0047 & \\
& & & $£ 9,986,930$ \\
& & & \\
Rent on review 1 & $£ 723,403$ & & \\
OMRV & $£ 590,330$ & & \\
Less current rent & $£ 624,000$ & $-£ 33,670$ & \\
YP in perp @ & $6.50 \%$ & 16.0047 & \\
PV @ & $6.50 \%$ & 0.8679 & \\
& & & $-4,467,686$ \\
Top slice & & $£ 133,073$ & \\
YP for years & $6.50 \%$ & 4.3232 & \\
PV @ & $6.50 \%$ & 0.8679 & \\
Top slice & & & 499,295 \\
YP for years & $6.50 \%$ & 4.3232 & \\
PV @ & $6.50 \%$ & 0.6335 & \\
& & & 679,878 \\
& & & \multirow{2}{*}{$£ 10,698,418$} \\
& Capital value & &
\end{tabular}

Valuation using shorthand equated yield Current rent $£ 624,000$

YP for term @ $\quad 10 \% \quad 2.0493$
OMRV

YP in perp@

PV@

Review 1

Less OMRV

Top slice 1

YP@

PV@

Review 2

Less OMRV

Top slice 2

YP@

PV@

\begin{tabular}{rr} 
& \\
$6.50 \%$ & $£ 644,083$ \\
$10 \%$ & 0.8070 \\
& \\
\hline 723,403 & \\
$10 \%$ & 4.0249 \\
$10 \%$ & 0.8070
\end{tabular}

$£ 1,278,781$

$8,318,698$

$£ 838,594$

$£ 781,709$

$£ 56,885$

$10 \% \quad 4.0249$

$10 \% \quad 0.5011$ 


\section{Scenario Y}

Pessimistic with escalator

Leisure park, edge of town, southern counties

Valuation date: Sept 2000

Lessee: Flix-U-Like

Input

Next review date 2002

Rent receivable $£ 624,000$

Lease expiry 2023

Rent reviews

Area $\mathrm{m}^{2}$

Screen

5 Rent review 1

4,541 Rent review 2 12

OMRV per $\mathrm{m}^{2}$

OMRV pa

All risks yield

Equated yield

Growth

$£ 100$

Rent review 1

$6.50 \%$ Rent review 2

$10 \%$

$3.95 \%$
$115.93 \% \quad 2.25$ years

$134.39 \% \quad 7.25$ years

2.25 years

7.25 years

12.25 years

17.25 years

\section{CV hardcore \\ $£ 9,690,355$}

$£ 723,403$ pa Over-rented on both reviews

$£ 838,594$ pa Escalator activated

CV equated yield

$£ 9,108,431$

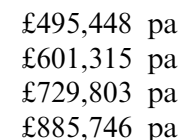

$£ 495,448$ pa

$£ 885,746$ pa

\begin{tabular}{|c|c|c|c|}
\hline \multicolumn{4}{|c|}{$\begin{array}{l}\text { With escalator } \\
\text { Valuation using hardcore }\end{array}$} \\
\hline \multicolumn{2}{|c|}{ Current rent } & \multicolumn{2}{|l|}{$£ 624,000$} \\
\hline YP in perp@ & $6.50 \%$ & 16.0047 & \\
\hline & & & $£ 9,986,930$ \\
\hline Rent on review 1 & $£ 723,403$ & & \\
\hline OMRV & $£ 454,100$ & & \\
\hline Less current rent & $£ 624,000$ & $-£ 169,900$ & \\
\hline YP in perp@ & $6.50 \%$ & 16.0047 & \\
\hline PV@ & $6.50 \%$ & 0.8679 & \\
\hline Top slice & & $£ 269,303$ & $-2,359,958$ \\
\hline YP for years & $6.50 \%$ & 4.3232 & \\
\hline PV@ & $6.50 \%$ & 0.8679 & \\
\hline & & & $1,010,433$ \\
\hline Top slice & & $£ 384,493.60$ & \\
\hline YP for years & $6.50 \%$ & 4.3232 & \\
\hline PV@ & $6.50 \%$ & 0.6335 & \\
\hline & & & $1,052,949$ \\
\hline & Capital v & alue & $£ 9,690,355$ \\
\hline
\end{tabular}

With escalator

Valuation using shorthand equated yield

Current rent $£ 624,000$

YP for term @ 10\% 2.0493

Review $1 \quad £ 723,403$

$£ 1,278,781$

YP @ $\quad 10 \% \quad 4.0249$

PV@ $\quad 10 \% \quad 0.8070$

Review $2 \quad £ 838,594$

YP@ $\quad 10 \% \quad 6.5240$

PV@ $\quad 10 \% \quad 0.5011$

OMRV $\quad £ 885,746$

YP @ in perp $\quad 6.50 \% \quad 16.0047$

PV@ $\quad 10 \% \quad 0.1932$

$2,349,637$

$2,741,387$

$2,738,626$

Capital value

$£ 9,108,431$ 


\section{Scenario $\mathbf{Y}$}

Pessimistic without escalator

Leisure park, edge of town, southern counties

Valuation date: Sept 2000

Lessee: Flix-U-Like

Input

Next review date 2002

Rent receivable $£ 624,000$

Lease expiry

Rent reviews

Area $\mathrm{m}^{2}$

Screen

OMRV per $\mathrm{m}^{2}$

OMRV pa

All risks yield

Equated yield

Growth

2023

5

4,541

12

$£ 100$

$£ 454,100$

$6.50 \%$

$10 \%$

$3.95 \%$
Lessor: Improvident Investors

Tenure Freehold

\section{Escalator}

Rent review $1 \quad 115.93 \% \quad 2.25$ years

Rent review $2 \quad 134.39 \% \quad 7.25$ years

OMRV

Rent review 1

Rent review 2

Rent review 3
2.25 years

7.25 years

12.25 years
CV hardcore

$£ 8,536,572$

$£ 723,403$ pa

$£ 838,594$ pa

$£ 495,448$ pa

$£ 601,315$ pa

$£ 729,803$ pa
$\mathrm{CV}$ equated yield $£ 8,198,082$

No escalators

No escalators

\begin{tabular}{|c|c|c|c|}
\hline \multicolumn{4}{|c|}{$\begin{array}{l}\text { No escalator } \\
\text { Valuation using hardcore }\end{array}$} \\
\hline \multirow{3}{*}{$\begin{array}{l}\text { Current rent } \\
\text { YP in perp@ }\end{array}$} & & $£ 454,100$ & \multirow{4}{*}{$£ 7,267,732$} \\
\hline & $6.50 \%$ & 16.0047 & \\
\hline & & & \\
\hline Current rent & $£ 624,000$ & & \\
\hline OMRV & $£ 454,100$ & & \\
\hline Top slice & & $£ 169,900$ & \\
\hline YP for years & $6.50 \%$ & 8.6050 & \\
\hline PV@ & $6.50 \%$ & 0.8679 & \\
\hline & & & $1,268,840$ \\
\hline & pital value & & $£ 8,536,572$ \\
\hline
\end{tabular}

No escalator

Valuation using shorthand equated yield

Current rent $£ 624,000$

YP for term@ $\quad 10 \% \quad 7.3141$

Estimated OMRV $\quad £ 729,803 \quad £ 4,564,019$

YP in perp@ 6.50\% 16.0047

PV@ 10\% 0.311

Over-rented on review 1

Over-rented on review 2

OMRV activated 


\section{Scenario Y}

Optimistic without escalator

Leisure park, edge of town, southern counties

Valuation date: Sept 2000

Lessee: Flix-U-Like

\section{Input}

Next review date 2002

Rent receivable $£ 624,000$

Lease expiry $\quad 2023$

Rent reviews 5

Area $\mathrm{m}^{2} \quad 4,541$

Screen 12

OMRV per $\mathrm{m}^{2} \quad £ 130$

OMRV pa $£ 590,330$

Equivalent yield $\quad 6.50 \%$

Equated yield $\quad 10 \%$

Growth $\quad 3.95 \%$
Lessor: Improvident Investors

$\begin{array}{lrr}\text { Tenure } \quad \text { Freehold } & \text { CV hardcore } & \text { CV equated yield } \\ £ 9,481,724 & £ 9,597,479\end{array}$

\section{Escalator}

Rent review $1 \quad 115.93 \% \quad 2.3$ years

Rent review $2 \quad 134.39 \% \quad 7.3$ years

$£ 723,403$ pa $£ 838,594$ pa

No escalator

No escalator

\section{OMRV}

Rent review 1

Rent review 2

2.3 years
7.3 years
12 years

$£ 644,083$ pa

$£ 781,709$ pa

Review to OMRV

Review to OMRV $£ 948,744$ pa

\begin{tabular}{|c|c|c|c|}
\hline \multicolumn{2}{|c|}{ Valuation using Hardcore } & $£ 590,330$ & \multirow[b]{3}{*}{$£ 9,448,052$} \\
\hline YP in perp @ & $6.50 \%$ & 16.0047 & \\
\hline & & & \\
\hline Current rent & $£ 624,000$ & & \\
\hline less OMRV & $£ 590,330$ & $£ 33,670$ & \\
\hline YP for years & $6.50 \%$ & 2.1144 & \\
\hline \multirow{2}{*}{\multicolumn{2}{|c|}{ Capital value }} & & $33,672.11$ \\
\hline & & & $£ 9,481,724$ \\
\hline
\end{tabular}

Valuation using shorthand equated yield

Current rent

YP for term @ 10\%

\section{OMRV}

YP in perp@ 6.50\% $\quad 16.0047$

PV@ $\quad 10 \% \quad 0.8070$

$£ 1,278,781$

Capital value

$8,318,698$

$£ 9,597,479$ 


\section{References}

1. Sayce, S. (2000) 'The new leisure leases: Do they measure up to institutional requirements?' Journal of Leisure Property, Vol. 1, No. 1, pp. 42-65.

2. Sayce, S. (1998) 'The new leisure parks: Do they have a future?', paper to the 28th International Symposium of the European Faculty of Land Use and Development, Kingston University, UK.

3. Sayce, ref. 1 above.

4. Sayce, S. (1998) 'An examination of the potential of leisure property as an institutional investment vehicle', unpublished $\mathrm{PhD}$ thesis, University of Reading.

5. See, for example, Drivers, J. (1999) Central London Office Leases - A Cultural Revolution?, London.

6. St Quintin (1997) A Review of Leisure Park Development in the UK, London, St Quintin.

7. Evans, C. and Morley, S. (2000) 'The future of leisure', in 2020: Visions of the Future Report, London, RICS Research Foundation.

8. It is estimated that the rating list now includes some 145,000 leisure and licensed property, which compares to 550,000 retail units: Soar, G. (2000) 'The effect of the rating revaluation', paper presented to What Happens Next in Leisure Property Briefing, London.

9. Knight Frank (1999) Leisure Property Review, Spring, London, Knight Frank; Knight Frank (1999) Leisure Property Review, Winter, London, Knight Frank.

10. The introduction of new planning policy guidance (PPG) notes (PPG 6 and PPG 13) in the mid-1990s effectively reduced the ability to develop in 'greenfield' locations and concentrated developments in town-centre locations.

11. Tinworth, A. (1998) 'Moving pitches - Cinema development', Estates Gazette, 5th December, pp. 96-98.

12. Hughes, P. (1999) 'Institutional interest in leisure investment: Covenant strength?', unpublished dissertation, Kingston University.

13. Sayce, ref. 2 above.

14. St Quintin, ref. 6 above.

15. Knight Frank, ref. 9 above.

16. DTZ Debenham Thorpe (1997) UK Leisure Parks Report, London, UK, Estates Gazette.

17. Sayce, ref. 1 above.

18. Lizieri, C., Crosby, N., Gibson, V., Murdoch, S. and Ward, C. (1997) 'Right space, right price: A study of the impact of changing business space patterns on the property market', RICS, London.

19. Colborne, A. and Hall, P. C. L. (1991) 'The profit method of valuation', Journal of Property Valuation \& Investment, Vol. 11, No. 1, pp. 43-49.

20. Butters, D. (1992) 'Leisure properties', in W. H. Rees (Ed) Valuation: Principles into Practice, London, UK, Estates Gazette.

21. Sayce, S. (1995) 'Leisure property: A question of profit?', Journal of Property Finance, Vol. 6, No. 1 pp. 7-27.

22. Marshall, H. and Williamson, H. (Eds) (1996) Law and Valuation of Leisure Property, 2nd edn, London, UK, Estates Gazette.

23. Urry, J. (1990) The Tourist Gaze, London, Sage Publications.

24. Evans and Morley, ref. 7 above.

25. Pine, B. J., Gilmore, J. H. and Pine, B. J. II (1999) The Experience Economy, Harvard Business School.

26. A1 use under the Use Classes Order, 1987 is for general retail use.

27. Sayce, ref. 1 above.

28. King Sturge (2000) Screen Wars? A Research Report, London, King Sturge.

29. Dobson, C. (2000) 'Jury still out on screen appeal', Retail Week, 12th May, p. 34.

30. King Sturge, ref. 28 above.

31. Ravenscroft, N. (1994) 'Leisure, consumerism and active citizenship in the UK', Working Papers in Land Management and Development No. 28, Reading, The University of Reading. 
32. Leisure Week (1999) 'Thinking outside the box', Special Report on Design, Leisure Week, 18th November.

33. Estates Gazette (2000) 'Licensed and leisure property: A joint supplement', Estates Gazette, Spring.

34. King Sturge, ref. 28 above, p. 4.

35. Morrison, A. (2000) 'Can the dream work?', Estates Gazette, 10th June, p. 89.

36. Armstrong, N. (1999) 'Lights! Canapes! Action!', Leisure Week, 17th June, pp. 33-34.

37. Swift, M. (1998) 'Digital debate', Leisure Week, 14th August, p. 19.

38. Fletcher, M. (1999) 'Designs on cinemas', Leisure Week, 26th February, p. 19.

39. Leisure Week, ref. 32 above.

40. Dodona Research (2000) 'Cinemagoing', Dodona: www.dodona.co.uk.

41. King Sturge, ref. 28 above.

42. Armstrong, ref. 36 above.

43. Dodona, ref. 40 above.

44. Ibid.

45. Twenty-nine new MPCs were due to open in 2000 according to King Sturge, ref. 28 above, p. 5.

46. King Sturge, ref. 28 above.

47. Osborne, H. (2000) 'Centre of attention', Estates Gazette, 25th March.

48. Kleinman, M. (1999) 'New kids on the block', Special Report on Cinemas, Leisure Week, 15th July.

49. The operator moves are now towards sites in mainland Europe, with few intending to increase their UK holdings (reported in interviews).

50. Nelson, B. and Davey, J. (1999) 'Cinemas' quest for a few dollars more', News Focus, Property Week, 27th August, p. 8.

51. Doury, N. (2000) 'Successfully integrating cinemas in retail and leisure complexes: An operator perspective', paper presented to the Leisure Property Forum Seminar, March, London.

52. Stephens, S. (2000) 'Behind the screens', Leisure Week, 6th April, p. 21.

53. Stephens, S. (2000) 'Risky business', Leisure Week, 23rd March, p. 25.

54. Sayce, ref. 1 above.

55. The rating lists compiled and issued in April 1995 and 2000 are based on rental values prevailing in 1993 and 1998 respectively.

56. McIntosh, A. P. J. and Sayce, S. (1998) Restaurants, High Streets and Employment Change, London, Leisure Property Forum.

57. ONS (Office for National Statistics) (2000) Family Spending 1995-1999, London, HMSO.

58. Hughes, ref. 12 above.

59. Insignia Richard Ellis (2000) Monthly Reports, various, London, Insignia Richard Ellis.

60. Investment Property Databank (2000) Monthly Reports, various, London, IPD.

61. Royal Institution of Chartered Surveyors (1994) Code of Measuring Practice, 4th edn, London, RICS.

62. Marshall and Williams, ref. 22 above.

63. DTZ Research (2000) Money into Property 2000, London, UK.

64. Walker, P. (2000) 'Valuing leisure investments', paper presented to Leisure Property Forum Seminar, January, London.

65. Based on a composite of IPD and Insignia Richard Ellis data.

66. DTZ, ref. 63 above.

67. Sayce, ref. 4 above.

68. Royal Institution of Chartered Surveyors (1997) Calculation of Worth: An Information Paper, London, RICS.

69. Sayce, ref. 2 above.

70. Hughes, ref. 12 above. 
71. Rose, A. (1999) 'Hoyts close to quitting UK multiplex scene', Estates Gazette, 21st August.

72. Hillson, S. (1998) 'Rent review developments', Journal of Rent Review and Lease Renewal, Vol. 18, No. 3, 247-252.

73. Scott, P. (1996) The Property Masters, London, E\&FN Spon.

74. Toynbee, P. (2000) 'Who's afraid of global culture?', in Hutton, W. and Giddens, A. (Eds) (2000) On the Edge, London, Jonathan Cape, p. 191.

75. Leadbetter, S. (1998) 'The attraction of leisure: An investor's view', paper presented to the Leisure Property Forum Seminar, 25th June.

76. Stephens, ref. 52 above. 